\title{
PERSPEKTIF SIKLUS HIDUP PERUSAHAAN DALAM HUBUNGAN ANTARA INVENTORI DAN KINERJA FINANSIAL
}

\author{
Ferry Setiawan \\ Nofrisel \\ Universitas Indonesia \\ frrystwn@gmail.com \\ nofrisel@yahoo.com
}

\begin{abstract}
Research regarding the relationship between inventory management and financial performance is so far inconclusive: some found it to be positive, others found it to be negative. One of the many factors that influence the variance, the organizational life cycle, will be explored in this research. Organizational life cycle might influence the relationship between inventory management and financial perfomance due to the different strategies and designs pursued by the organizations along each of their life cycle stages. This study use a sample set of 33 manufacturing companies listed in BEl, with 7 years observation period. A regression analysis is performed with dummy variables of organizational life cycle, resulting from a cluster analysis with k-mean method. Regression analysis and cluster analysis are all done with Stata. The result shows that the relationship between inventory and financial performance is positive in the early growth stage of organization life cycle and turns to negative at late growth stage. The relationship is inconclusive at the conception and stability stage of organizational life cycle. Therefore, we can conclude that in making decisions about inventory, firms should consider what stage of organizational life cycle they are currently in so that the decisions made can impact the financial performance positively.
\end{abstract}

Keywords: Organizational Life Cycle, Financial Performance, Inventory Management

\section{LATAR BELAKANG}

Secara umum, manajemen inventori akan dipandang baik apabila jumlah inventori dalam suatu perusahaan dapat dijaga atau ditekan pada jumlah yang rendah. Jumlah inventori yang rendah tersebut dipandang akan menimbulkan efisiensi operasional yang pada akhirnya akan meningkatkan kinerja finansial perusahaan (Eroglu \& Hofer, 2011). Namun, pandangan umum tentang hubungan antara manajemen inventori dan kinerja finansial perusahaan tersebut ternyata belum disetujui secara aklamasi (Elsayed \& Wahba, 2016). Di satu sisi, sebagian penelitian menunjukkan hubungan yang positif antara manajemen inventori dan kinerja finansial perusahaan (Capkun, Hameri, \& Weiss, 2009; Hofer, Eroglu, \& Hofer, 2012; Shah \& Shin, 2007; Koumanakos, 2008). Sebaliknya, penelitian ilmiah yang menunjukkan hubungan negatif antara manajemen inventori dan kinerja finansial perusahaan juga tidak sedikit (Cannon, 2008; Vastag \& Whybark, 2005; Steinker \& Hoberg, 2013).

Perbedaan hasil penelitian tentang hubungan antara manajemen inventori dan kinerja finansial perusahaan tersebut diduga dipengaruhi oleh beberapa factor: perbedaan peran perusahaan dalam rantai 
pasoknya (Obermaier \& Donhauser, 2012), perbedaan tipe inventori yang dimiliki oleh perusahaan, antara inventori workin-progress, inventori finished goods, dan inventori raw material (Bendig, Brettel, \& Downar, 2018), perbedaan kekuatan perusahaan dalam persaingan industri (Blazenko \& Vandezande, 2003), serta kesalahan cara pengukuran dan kesalahan pemilihan variabel pengukuran inventori dan kinerja finansial (Klingenberg, Timberlake, Geurts, \& Brown, 2013).

Di antara semua faktor tersebut, faktor siklus hidup perusahaan adalah salah satu yang belum diteliti secara mendalam (Elsayed \& Wahba, 2016). Padahal faktor siklus hidup perusahaan ini sangat relevan dalam hubungan antara manajemen dan kinerja finansial

perusahaan. Penelitian Blazenko \& Vandezande (2003) menemukan bahwa perusahaan yang berada dalam tahapan siklus hidup cukup dewasa memiliki kekuatan untuk mempertahankan tingkat inventori yang tinggi dan malah menguntungkan perusahaan secara finansial. Tingkat inventori yang tinggi tersebut bisa digunakan untuk membanjiri pasar dengan produk agar bisa bersaing dengan kompetitor yang sudah terlebih dahulu menurunkan harga produk mereka.

Penelitian Elsayed \& Wahba (2016) yang dijadikan acuan untuk penelitian ini dilakukan dengan menggunakan data perusahaanperusahaan di India. Sejauh ini, penulis belum menemukan penelitian serupa dilakukan dengan menggunakan data perusahaan- perusahaan yang beroperasi di Indonesia. Penulis berpendapat bahwa penelitian ini akan banyak membawa manfaat, karena perusahaan-perusahaan di Indonesia sangat beragam bila dilihat dari konteks tahapan siklus hidupnya. Berdasarkan data StartupRanking di tahun 2016, Indonesia menempati peringkat ketiga dunia sebagai negara yang memiliki jumlah perusahaan startup paling banyak. Selain itu, perusahaan-perusahaan di Indonesia juga sebagian besar masih beroperasi dalam industri manufaktur, sehingga manajemen inventori memainkan peran yang penting untuk perusahaan bisa mendapat kinerja finansial yang baik. Berdasarkan laporan United Nations Industrial Development Organization (UNIDO) pada tahun 2016, Indonesia menempati urutan 10 secara global dalam daftar negara dengan total volume produksi manufaktur paling tinggi. Saat ini, berdasarkan survei Nikkei Indonesia pada tahun 2018, industri manufaktur Indonesia menghadapi beberapa tantangan yang nyata: tingkat permintaan dari pasar internasional yang menurun dan meningkatnya harga bahan baku produksi sebagai akibat dari melemahnya nilai tukar mata uang Rupiah terhadap Dollar Amerika Serikat. Melihat konteks tersebut, penulis berpendapat bahwa penelitian ini sangat penting untuk memberi pemahaman bagi para pembuat kebijakan dalam perusahaan, secara lebih spesifik perusahaanperusahaan yang bergerak dalam industri manufaktur, agar bisa membuat keputusan terkait manajemen inventori dengan

mempertimbangkan tahapan siklus hidup perusahaan, agar keputusan tersebut bisa memaksimalkan kinerja finansial perusahaan dalam masa-masa yang menantang ini.

\section{KAJIAN PUSTAKA DAN PENGEMBANGAN HIPOTESIS}

\section{Manajemen Inventori}

Silver (1981) mengemukakan bahwa manajemen inventori secara umum terkait dengan proses pengambilan keputusan tentang stok barang atau stok inventori perusahaan yang biasanya berjumlah besar, dengan terus mempertimbangkan berbagai kombinasi berbagai faktor dan batasan. Ada beberapa biaya yang relevan di dalam proses manajemen inventori: replenishment cost atau biaya untuk memesan barang yang telah habis, carrying cost atau biaya penyimpanan inventori serta biaya risiko barang rusak atau kedaluwarsa, costs of 
insufficient supply in the short run atau biaya yang timbul setiap kali ada permintaan konsumen yang tidak bisa dipenuhi oleh perusahaan karena stok barang tidak mencukupi, dan system control cost atau biaya untuk atau mendapatkan data untuk implementasi sistem inventori baru.

Salah satu tujuan utama dilakukannya manajemeninventoriadalahagarperusahaan bisa memaksimalkan keuntungan finansial. Literatur yang membahas hubungan antara manajemen inventori dengan kinerja finansial perusahaan secara umum terbagi menjadi dua kutub, hubungan positif dan negatif.

\section{Hubungan Positif Inventori-Kinerja}

Mishra, Modi, \& Animesh (2013) menemukan adanya hubungan positif antara efisiensi inventori dan tingkat pengembalian saham perusahaan. Penelitian Hendricks, Singhal, \& Stratman (2007) menemukan bahwa perusahaan yang berinvestasi dalam sistem teknologi informasi seperti Enterprise Resource Planning (ERP), Supply Chain Management (SCM), atau Customer Relationship Management (CRM), menunjukkan tingkat pengembalian saham jangka panjang dan profitabilitas yang lebih baik. Penelitian Shah \& Shin (2007) menemukan bahwa variabel kinerja inventori memiliki peran mediasi yang signifikan dalam hubungan antara investasi dalam sistem teknologi informasi dan kinerja finansial perusahaan. Penelitian Steinker \& Hoberg (2013) menghasilkan dua kesimpulan yang berbeda. Ukuran inventori yang pertama, Abnormal Inventory Growth $(A B I)$, berkorelasi secara negatif dengan tingkat pengembalian saham yang bersifat abnormal. Namun hasil penelitian dari metode pengukuran inventori yang kedua memberikan hasil yang kontras dengan hasil pengukuran pertama.

\section{Hubungan Negatif Inventori-Kinerja}

Pengukuran inventori yang kedua dalam penelitian Steinker \& Hoberg (2013) menggunakan proxy volatilitas inventori (IV) sebagai metrik dari dinamika inventori. Ditemukan bahwa perusahaan yang memiliki nilai IV yang tinggi menghasilkan tingkat pengembalian saham yang bersifat abnormal. Cannon (2008)menemukan dalam beberapa perusahaan yang diobservasi dalam penelitian, peningkatan dalam kinerja inventori ternyata memiliki asosiasi dengan penurunan kinerja perusahaan secara keseluruhan. Demeter (2003) menemukan bahwa adanya strategi manufaktur yang baik dalam suatu perusahaan tidak selalu menghasilkan perbaikan dalam inventory turnover. Penelitian Vastag \& Whybark (2005), juga menemukan bahwa tidak ada perbedaan signifikan dalam hal inventory turnover antara perusahaan yang memiliki kinerja tinggi dan perusahaan yang memiliki kinerja rendah.

\section{Faktor Penyebab Variasi Sifat Hubungan Inventori-Kinerja}

Obermaier \&menjelaskan bahwa manajemen inventori dan kinerja finansial perusahaan bisa saja dipengaruhi oleh perbedaan peran perusahaan dalam rantai pasoknya. Kebijakan inventori rendah pada perusahaan hulu akan menimbulkan risiko proses produksi terhambat. Kebijakan inventori tinggi pada perusahaan hilir akan menimbulkan risiko inventori rusak tidak terpakai, sehingga akan menurunkan keuntungan finansial. Bendig, Brettel, \& Downar (2018) melihat variasi hubungan bisa dijelaskan oleh perbedaan tipe inventori yang dimiliki oleh perusahaan, antara work-in-progress, finished- goods, atau raw material. Blazenko \& Vandezande (2003) meneliti perbedaan kekuatan pasar perusahaan sebagai penyebab variasi hubungan tersebut. Perusahaan yang memiliki kekuatan pasar yang besar biasanya memilih untuk mengurangi tingkat inventorinya karena risiko negatif terjadinya kehabisan stok barang akan relatif lebih kecil. Klingenberg, Timberlake, Geurts, \& Brown (2013) mencoba menjelaskan bahwa 
perbedaan yang terjadi disebabkan oleh kesalahan cara pengukuran dan kesalahan pemilihan variabel pengukuran. Rasio finansial mereka nilai tidak cocok untuk mengukur efek inisiatif manajemen inventori.

\section{Siklus Hidup Organisasi}

Di antara semua faktor yang diduga mempengaruhi hubungan antara manajemen inventori dan kinerja finansial perusahaan, faktor siklus hidup perusahaan adalah salah satu yang belum diteliti secara mendalam (Elsayed \& Wahba, 2016). Teori Siklus Hidup Organisasi mengemukakan bahwa organisasi pada dasarnya bertumbuh melalui beberapa proses atau tahapan kehidupan dan masing- masing proses atau tahapan tersebut memiliki karakteristik atau ciri-ciri yang berbeda (Tam \& Gray, 2016). Secara umum ada 4 tahapan kehidupan yang biasanya dilewati oleh perusahaan dalam masa kehidupannya (Lyden, 1975; Kazanjian \& Drazin, 1990).

Tahap Pembentukan. Dalam tahapan awal ini, perusahaan biasanya berumur muda, berskala kecil, tidak terstruktur dengan baik, fleksibel, dan bersifat informal dalam mengelola bisnis.

Tahap Pertumbuhan Awal. Dalam tahap ini, terjadi perubahan signifikan dalam alur kerja perusahaan, sehingga ukuran biasanya meningkat pesat. Perusahaan menjadi lebih agresif dalam kebijakankebijakan operasionalnya demi mencari keuntungan yang lebih besar.

Tahap Pertumbuhan Akhir. Dalam tahap ini, Sistem, budaya, dan praktik keseharian perusahaan sudah menjadi norma yang rutin dilakukan. Perusahaan sudah bisa mendominasi pangsa pasar, sehingga prioritas mulai bergeser menjadi mengejar efisiensi biaya perusahaan.

Tahap Stabilitas. Dalam tahapan ini, biasanya mulai terjadi penurunan tingkat penjualan, margin keuntungan semakin mengecil, dan utang semakin meningkat. Tahapan ini bila tidak dikelola dengan baik bisa berujung pada kematian perusahaan.
Faktor siklus hidup perusahaan ini sangat relevan dalam hubungan antara manajemen inventori dan kinerja finansial perusahaan. Memasukkan faktor siklus hidup perusahaan dalam persamaan hubungan antara manajemen inventori dan kinerja finansial perusahaan berarti mempertimbangkan kenyataan bahwa mengelola inventori tidak bisa diisolasi dari pengaturan organisasional yang lain (De Vries, 2011). Selain itu, untuk bisa membuat kebijakan-kebijakan yang menghasilkan perbaikan dalam berbagai aspek bagi perusahaan dari waktu ke waktu, para pembuat keputusan harus terlebih dahulu mempertimbangkan di tahap siklus hidup mana perusahaan mereka berada (Rahimi \& Fallah, 2015). Penelitian Hasan \& Cheung pada tahun 2018 juga menemukan bahwa ada perbedaan yang signifikan dalam kepemilikan organization capital, misalnya praktek bisnis, proses bisnis, sistem, desain, dan budaya perusahaan, antara perusahaan-perusahaan yang berada dalam tahapan siklus hidup yang berbeda. Ardianti (2013) menemukan bahwa perusahaan yang berada dalam tahapan siklus hidup berbeda juga akan menghadapi tantangan yang berbeda-beda. Hasil analisis menunjukkan bahwa di antara tiga belas hambatan yang diteliti, terdapat perbedaan yang signifikan dalam 9 hambatan yang dihadapi oleh perusahaan-perusahaan yang berada dalam tahapan siklus hidup yang berbeda.

Contoh nyata pengaruh tahapan siklus hidup perusahaan terhadap hubungan antara manajemen inventori dengan kinerja finansial perusahaan ini digambarkan juga dalam penelitian Blazenko \& Vandezande (2003). Berlawanan dengan pandangan umum bahwa tingkat inventori yang tinggi akan meningkatkan biaya, penelitian tersebut menemukan bahwa perusahaan yang berada dalam tahapan siklus hidup cukup matur memiliki kekuatan untuk mempertahankantingkatinventoriyang tinggi dan malah menguntungkan perusahaan secara finansial. Tingkat inventori yang tinggi 
tersebut bisa digunakan untuk membanjiri pasar dengan produk agar bisa bersaing dengan kompetitor yang sudah terlebih dahulu menurunkan harga produk mereka. Elsayed \& Wahba (2016) juga menemukan bahwa hubungan positif antara manajemen inventori dan kinerja finansial perusahaan terjadi saat siklus hidup

perusahaan berada dalam tahapan rapid growth dan revival, sedangkan pada tahap initial growth dan maturity, hubungan tersebut menjadi bersifat negatif.

\section{Hipotesis}

Berdasarkan metodologi penelitian yang telah dijelaskan di atas, maka untuk dapat meneliti perspektif siklus hidup perusahaan dalam hubungan antara manajemen inventori dan kinerja finansial perusahaan, hipotesis penelitian akan dijabarkan dalam penjelasan berikut ini.

Perusahaan-perusahaan yang berada pada tahap pembentukan, biasanya bersifat lebih sensitif terhadap persaingan, dan akan mengambil kebijakan-kebijakan yang lebih proaktif untuk berusaha bertahan hidup dalam industri tempat mereka beroperasi (Dodge, Fullerton, \& Robbins, 1994). Dorongan dan kebutuhan untuk bertahan hidup tersebut biasanya membuat perusahaan mengambil keputusan yang cenderung lebih berisiko. Misalnya dalam keputusan-keputusan yang terkait dengan konteks manajemen inventori, perusahaan biasanya mengambil keputusan untuk menyimpan inventori pada tingkat yang lebih tinggi untuk menghindari kehabisan barang. Keputusan tersebut cenderung akan mempengaruhi kinerja perusahaan secara negatif, karena perusahaan dalam tahap pertumbuhan awal ini biasanya memiliki tingkat permintaan yang berfluktuasi, jumlah pemesanan yang relatif kecil, serta pilihan yang terbatas dalam pembelian dan alternatif pemasok.

$\mathrm{H} 1$ : Tingkat inventori dan kinerja perusahaan berkorelasi secara negatif pada tahapan siklus hidup pembentukan.
Perusahaan-perusahaan yang berada pada tahapan pertumbuhan awal, biasanya sudah beroperasi secara lebih stabil, memiliki tingkat permintaan produk dan potensi keuntungan yang lebih besar, sehingga kebutuhan serta dorongan perusahaan tersebut untuk bertahan hidup tidak lagi sebesar pada perusahaan yang berada pada tahapan awal pertumbuhan. Dalam konteks manajemen inventori, untuk bisa memenuhi permintaan pasar yang cenderung meningkat, perusahaan biasanya akan membuat keputusan untuk menyimpan stok inventori pada tingkat yang tinggi. Keputusan tersebut cenderung akan mempengaruhi kinerja perusahaan secara positif karena pada perusahaan yang berada pada tahapan pertumbuhan pesat, inventori berperan penting untuk menerjemahkan permintaan pasar menjadi penjualan, sehingga tingkat layanan kepada konsumen membaik, perusahaan bisa membuka geraigerai baru, atau bahkan bisa menambahkan lini produk baru (Gaur \& Kesavan, 2007).

$\mathrm{H} 2$ : Tingkat inventori dan kinerja perusahaan berkorelasi secara positif pada tahapan siklus hidup pertumbuhan awal.

Perusahaan yang berada pada tahapan hidup pertumbuhan akhir terus mengalami pertumbuhan kekuatan pasar dan pangsa pasar dan membuat perusahaan dalam tahapan hidup ini biasanya mengadopsi strategi yang lebih bersifat menghindari risiko dan berfokus lebih pada profitabilitas. Peningkatan profitabilitas ini bisa dicapai salah satunya dengan mengurangi biayabiaya seperti biaya inventori. Dengan meningkatnya kekuatan pasar perusahaan, risiko serta dampak negatif dari kehabisan stok inventori akan menjadi lebih kecil, sehingga perusahaan cenderung merespon dengan mengurangi tingkat inventorinya (Blazenko \& Vandezande, 2003). Jadi, dalam tahapan hidup dewasa ini, tingkat inventori perusahaan akan berdampak negatif terhadap kinerja finansial perusahaan. 
H3: Tingkat inventori dan kinerja perusahaan berkorelasi secara negatif pada tahapan siklus hidup pertumbuhan akhir.

Perusahaan yang berada dalam tahapan hidup stabilitas membutuhkan adanya pergeseran dalam strategi mereka untuk bersaing di pasar, dan kadang membutuhkan adanya pengenalan produk baru perusahaan ke pasar. Berarti perusahaan dalam tahap ini akan kembali lebih berfokus pada peningkatan market share dibanding peningkatan profitabilitas. Peningkatan market share tersebut bisa dicapai dengan kebijakan untuk meningkatkan jumlah inventori yang dimiliki, agar service level bisa dijaga pada tingkat yang tinggi sehingga menghasilkan peningkatan penjualan. Artinya, dalam tahapan stabilitas ini, tingkat inventori perusahaan akan berhubungan secara positif dengan kinerja finansial perusahaan.

H4: Tingkat inventori dan kinerja perusahaan berkorelasi secara positif pada tahapan siklus hidup stabilitas.

\section{METODE PENELITIAN}

Untuk dapat menjawab hipotesis di atas, penelitian ini akan mengadaptasi model penelitian Elsayed \& Wahba (2016): menggunakan total aset perusahaan.

LVG: Financial Leverage perusahaan; diukur dengan menggunakan rasio total utang terhadap total aset perusahaan.

YER: Kontrol efek waktu terhadap kinerja perusahaan.

SEC: Klasifikasi industri yang dimasukkan untuk mengontrol perbedaan kinerja yang ada di antara berbagai industri.

\section{Variabel Dependen}

Variabel dependen yang akan diteliti dalam penelitian ini adalah kinerja finansial perusahaan yang akan diukur menggunakan Return on Asset (ROA). Untuk mencapai tujuan mengukur kinerja finansial perusahaan, ada dua pilihan ukuran yang bisa digunakan, yaitu ukuran yang berbasis nilai akuntansi atau ukuran yang berbasis nilai pasar saham. Penelitian ini memilih untuk menggunakan ukuran yang berbasis akuntansi dibanding ukuran yang berbasis nilai saham perusahaan karena fokus penelitian ini adalah untuk menilai kinerja operasional perusahaan, bukan kinerja perusahaan berdasarkan persepsi pasar saham. ROA dipilih untuk digunakan sebagai ukuran untuk menilai kinerja dibanding ROE karena ROA mencerminkan hasil operasional, bukan keputusan struktur

$$
\begin{aligned}
R O A_{i t}=\boldsymbol{\alpha} & +\beta_{1} I V P_{i t}+\beta_{2} I V P_{i t} * O L C_{i t} \\
& +\beta_{3} S I Z_{i t}+\beta_{4} L V G_{i t}+\beta_{5} Y E R_{i t} \\
& +\beta_{6} S E C_{i t}+\mu_{i}
\end{aligned}
$$

ROA : Kinerja finansial perusahaan; diukur menggunakan Return on Asset (ROA).

IVP: Kinerja inventori perusahaan; diukur menggunakan rasio inventori terhadap penjualan.

OLC: Variabel siklus hidup organisasi. Penjelasan mengenai pengukuran OLC ini akan dijelaskan dalam bagian berikutnya.

SIZ: Ukuran perusahaan; diukur modal perusahaan seperti yang difokuskan oleh ROE (Elsayed \& Wahba, 2016). Nilai ROA yang tinggi menunjukkan nilai kinerja finansial perusahaan yang tinggi. Nilai ROA yang rendah menunjukkan kinerja finansial perusahaan yang rendah. ROA ini dihitung dengan rumus Net Income perusahaan dibagi dengan Total Assets.

\section{Variabel Independen}

Variabel independen utama dalam 
model di atas adalah kinerja inventori perusahaan (IVP). Variabel tersebut akan diukur dengan menggunakan rasio inventori terhadap penjualan. Rasio ini digunakan karena pengukuran tingkat inventori suatu perusahaan yang digunakan untuk mencapai tingkat volume penjualan tertentu secara umum dapat memberi gambaran tingkat inefisiensi manajemen inventori dalam perusahaan tersebut (Shah \& Shin, 2007).

Nilai inventori dan penjualan yang digunakan berasal dari satu periode yang sama karena ingin melihat apakah perusahaan dapat menjaga tingkat inventorinya pada nilai yang rendah terkait dengan tingkat penjualannya pada periode tersebut (Elsayed \& Wahba, 2016). Nilai IVP yang tinggi menandakan kinerja inventori perusahaan yang buruk, karena diasumsikan perusahaan menjalankan praktik manajemen inventori yang tidak baik sehingga tingkat inventori menjadi tinggi atau tidak ramping. Sedangkan nilai IVP yang rendah menandakan kinerja inventori perusahaan yang baik, karena diasumsikan perusahaan menjalankan praktik manajemen inventori yang baik sehingga tingkat inventori bisa dijaga pada tingkat yang rendah dan ramping.

\section{Variabel Moderator}

Dalam penelitian ini, variabel siklus hidup organisasi berperan sebagai variabel moderator dalam hubungan antara manajemen inventori dan kinerja finansial perusahaan. Peran moderator ini akan dianalisis dengan melakukan uji regresi terpisah terhadap kelompok-kelompok perusahaan sesuai dengan tahapan siklus hidup masing-masing. Pengelompokan sampel perusahaan- perusahaan yang ada ke dalam tahapan hidup

masing-masing akan dilakukan dengan menggunakan cluster analysis, sebuah teknik pengelompokan yang bertujuan untuk mencari sifat-sifat homogen dari anggota-anggota dalam kelompok yang sama dan sekaligus sifat-sifat heterogen dari anggota-anggota dalam kelompok yang berbeda. Variabel yang digunakan untuk pengelompokan ini adalah rasio pertumbuhan penjualan (SGR), intensitas kapital perusahaan (FIX), dan usia perusahaan (AGE) (Anthony \& Ramesh, 1992; Hasan \& Cheung, 2018). SGR diukur menggunakan rasio perubahan penjualan relatif terhadap penjualan tahun sebelumnya dibagi dengan penjualan tahun sebelumnya. FIX diukur menggunakan rasio aset tetap terhadap total aset. AGE diukur dengan mengurangkan tahun penelitian dengan tahun berdirinya perusahaan.

Metode clustering K-Mean akan digunakan untuk membagi observasi yang digunakan ke dalam 4 kelompok yang berbeda, sesuai dengan 4 variabel siklus hidup organisasi di atas. Metode ini membagi observasi dalam set data yang ada ke dalam kelompok yang jumlahnya sudah ditentukan sejak awal. Objektif dari metode clustering menggunakan K-mean ini ada dua, yaitu membuat observasi dalam masing-masing cluster bersifat semirip mungkin antara satu dengan yang lain dan tujuan kedua adalah untuk membuat masing- masing cluster memiliki karakter yang seberbeda mungkin dengan karakteristik cluster lainnya (Ahmad, 2007). Langkah pertama dalam cluster analysis menggunakan metode ini adalah dengan menentukan secara acak 4 observasi untuk dijadikan centroid awal dari masing-masing cluster.

Penentuan secara acak ini dilakukan karena di tahap awal ini titik tengah masing-masing cluster belum diketahui. Langkah kedua adalah untuk menempatkan observasi yang terdekat dengan titik tengah masing-masing cluster, mengelompokkan mereka menjadi satu kelompok. Langkah ketiga setelah kelompok-kelompok terbentuk adalah dengan menghitung ulang titik tengah dari masing-masing kelompok tersebut. Langkah kedua dan ketiga ini akan terus diulang dalam suatu siklus sampai pada akhirnya nilai titik tengah dari 
masing-masing cluster tidak lagi berubah. Di titik itulah berarti proses clustering sudah selesai dan kelompok yang berbeda dari masing-masing observasi sudah terbentuk. Metode K-mean digunakan karena metode ini dipandang sebagai salah satu metode yang paling sederhana dan yang paling efisien untuk melakukan cluster analysis (Ahmad, 2007). Selain itu, metode K-mean ini digunakan karena penelitian ini sudah menetapkan bahwa tahapan siklus hidup yang akan diteliti berjumlah sebanyak 4 tahap. Jadi sejak awal, penelitian ini sudah menetapkan bahwa seluruh observasi yang dijadikan sampel akan dibagi ke dalam 4 kelompok sesuai dengan tahapan siklus hidup masing- masing. Apabila saat melakukan cluster analysis jumlah kelompok belum diketahui, maka metode K-mean ini tidak dapat digunakan dan penelitian harus menggunakan alternatif lain metode cluster analysis, misalnya metode clustering menggunakan Ward's Algorithm.

\section{Variabel Kontrol}

Variabel kontrol yang digunakan dalam penelitian ini adalah variabel ukuran perusahaan (SIZ), financial leverage perusahaan (LVG), variabel waktu untuk mengontrol kinerja perusahaan (YER), dan variabel dummy klasifikasi industri (SEC). Variabel SIZ dimasukkan untuk bisa menangkap efek dari economies of scale dan fluktuasi inventori antara perusahaan besar dan perusahaan kecil. Variabel LVG dimasukkan karena leverage yang tinggi bisa saja mengurangi kemampuan perusahaan untuk membiayai investasi yang terkait dengan inventori. Variabel YER dimasukkan karena kinerja suatu organisasi sangat mungkin berubah secara signifikan selama periode observasi penelitian ini. Variabel SEC dimasukkan karena hubungan antara kinerja inventori dan kinerja finansial perusahaan bisa bervariasi tergantung jenis industri ataupun sub-industri masing-masing perusahaan (Elsayed \& Wahba, 2016).

\section{Data dan Sampel}

Penelitian ini menggunakan data sekunder laporan keuangan perusahaan, yaitu neraca, laporan laba rugi, dan laporan arus kas. Data- data laporan keuangan tersebut pertama-tama didapat dari Wharton Research Data Centre (WRDC). Sampel perusahaan terdiri dari perusahaanperusahaan non-jasa dan non- keuangan yang terdaftar pada Bursa Efek Indonesia. Perusahaan-perusahaan manufaktur ini disaring dengan menggunakan metode purposive sampling, yaitu metode sampling dengan kriteria pemilihan yang telah ditetapkan sebelumnya. Dalam penelitian ini, kriteria pemilihan tersebut adalah sebagai berikut: a. Perusahaan termasuk dalam kategori industri non-jasa dan non-keuangan berdasarkan pembagian klasifikasi industri Standard Industry Classification (SIC) Code.

b. Peneliti akan menyaring perusahaanperusahaan tersebut lebih jauh berdasarkan klasifikasi sub-industri, yaitu sub-industri manufaktur (kode SIC 2000-3999). c. Rentang periode observasi penelitian ini adalah 7 tahun, dari tahun 2010 sampai tahun 2016.

Dari kriteria pemilihan tersebut, didapatkan total 33 perusahaan yang memiliki data lengkap dengan masa observasi selama 7 tahun dari 20102016. Pemilihan perusahaan dalam satu sub-industri manufaktur bertujuan untuk menghindari perbedaan-perbedaan karakteristik keuangan antar perusahaan yang berbeda industri. Sedangkan subindustri manufaktur dipilih karena variabel utama yang akan diteliti terkait dengan inventori. Perusahaan-perusahaan dalam industri keuangan dan industri lainnya memiliki cara pencatatan dan natur akun inventori yang berbeda dengan tujuan penelitian ini. Selain itu, jumlah perusahaan dalam industri manufaktur juga lebih banyak daripada jumlah perusahaan dalam industri lain. Periode observasi selama 7 tahun dibutuhkan agar hasil yang didapat bisa bersifat representatif. 


\section{Metode Analisis Data}

Analisis Statistik Deskriptif. Setelah variabel dependen dan variabel independen ditentukan, data-data keuangan perusahaan akan diolah sampai siap untuk diestimasi berdasarkan model yang telah ada. Analisis pertama yang dilakukan adalah analisis statistik deskriptif dari masing-masing model penelitian dengan menggunakan Stata. Apabila dalam analisis statistik deskriptif ditemukan adanya data bernilai outlier, maka akan dilakukan metode winsorizing. (Liao \& Brooks, 2016). Penjelasan tentang cluster analysis juga akan dilakukan pada bagian ini.

Pemilihan Teknik Estimasi. Dalam penelitian ini, model penelitian yang digunakan adalah model regresi untuk data panel. Secara umum, ada tiga pilihan metode regresi untuk menganalisis data panel, yaitu teknik estimasi pooled least square, teknik estimasi fixed effect, dan teknik estimasi random effect. Pertama-tama, Pengujian $F$ Test akan dilakukan untuk menentukan apakah penelitian ini akan menggunakan teknik estimasi pooled OLS atau fixed effect. Langkah berikutnya adalah melakukan Uji Hausman, yang bertujuan untuk bisa mengetahui apakah teknik estimasi yang sesuai digunakan dalam penelitian ini adalah metode fixed effect atau random effect. Semua pengujian akan dilakukan dengan menggunakan Stata.

Uji Asumsi Klasik. Dalam penelitian ini, ada beberapa uji asumsi klasik yang akan dilakukan. Uji normalitas akan dilakukan dengan menggunakan Stata, dengan menggunakan Uji Saphiro-Wilk yang akan menghasilkan nilai statistik beserta probalitasnya. Uji multikolinearitas, yang bertujuan untuk mendeteksi adanya penyakit statistik berupa hubungan signifikan antara variabel-variabel independen yang digunakan, dilakukan dengan menggunakan fasilitas matriks korelasi yang ada di dalam Stata. Uji heteroskedastisitas, yang bertujuan untuk mendeteksi penyakit statistik berupa adanya persebaran variasi eror yang tidak konstan antara satu observasi dengan observasi yang

lainnya, dilakukan dengan menggunakan fasilitas pengujian Modified Wald Test for Groupwise Heteroskedasticity pada Stata. Uji autokorelasi, yang bertujuan untuk mendeteksi penyakit statistik berupa korelasi antara eror pada satu periode observasi dengan eror periode observasi sebelumnya, dilakukan dengan menggunakan fasilitas pengujian Woolridge Test yang ada dalam Stata.

Interpretasi Hasil Regresi. Setelah uji asumsi klasik telah dilakukan, analisis

Tabel 1 Statistik Deskriptif Variabel Penelitian

\begin{tabular}{ccccccc}
\hline Min & Batas Bawah & Mean & $\begin{array}{c}\text { Batas } \\
\text { Atas }\end{array}$ & Max & St. Dev. \\
\hline ROA & 0.012 & -0.148 & 0.127 & 0.401 & 0.382 & 0.091 \\
IVP & 0.058 & -0.088 & 0.171 & 0.430 & 0.392 & 0.086 \\
SIZ & 2,682 & $(27,753,865)$ & $7,946,135$ & $43,646,135$ & $44,200,000$ & $11,900,000$ \\
LVG & 0.094 & -0.151 & 0.386 & 0.884 & 0.884 & 0.179 \\
SGR & -0.159 & -0.301 & 0.101 & 0.504 & 0.397 & 0.134 \\
FIX & 0.026 & -0.195 & 0.357 & 0.909 & 0.803 & 0.184 \\
AGE & 15 & -9.517 & 41.909 & 93.335 & 87 & 17.142 \\
\hline
\end{tabular}


berikutnya yang harus dilakukan adalah analisis hasil regresi. Untuk mengukur efek moderasi dari siklus hidup perusahaan terhadap hubungan antara manajemen inventori dan kinerja finansial perusahaan, uji regresi akan dilakukan untuk setiap variabel dummy siklus hidup perusahaan. Semua regresi akan dilaksanakan dengan menggunakan Stata. Terdapat tiga analisis hasil statistik yang harus kita lakukan terhadap hasil regresi. Analisis statistik $\mathrm{F}$ dilakukan untuk melihat apakah setiap variabel independen yang ada di dalam sebuah model bersama- sama mempengaruhi variabel dependen secara signifikan. Analisis R2 dilakukan untuk melihat apakah model regresi yang digunakan dapat menjelaskan dengan baik variasi yang terjadi pada variabel dependen. Analisis statistik $t$ ini dilakukan untuk memeriksa signifikansi pengaruh masingmasing variabel independen terhadap variabel dependen yang digunakan dalam model.

\section{HASIL PENELITIAN \\ Analisis Statistik Deskriptif}

Dalam tabel statistik deskriptif yang ditampilkan, bisa dilihat statistik deskriptif untuk variabel-variabel yang digunakan dalam penelitian. Data-data yang ditampilkan telah melalui satu kali proses winsorizing, karena pada data awal banyak mengandung nilai outlier, yaitu rata-rata ditambah tiga kali standar deviasi (Liao \& Brooks, 2016). Persebaran data bisa dilihat menjadi lebih sempit, dilihat dari standar deviasi hampir setiap variabel yang mengecil. Nilai maksimum dan minimum dari masing-masing variabel pun hampir semua tidak ada yang melebihi batas atas dan batas bawah data. Namun, karena winsorizing dalam tahap ini hanya dilakukan sebanyak satu kali, tetap masih ada beberapa model yang memiliki observasi outlier. Tingginya variabilitas ini diperkirakan disebabkan oleh karakteristik data keuangan yang digunakan serta panjang periode observasi penelitian.
Clustering dalam penelitian ini dilakukan dengan menggunakan metode K-mean dan akan membagi klasifikasi atau kategori siklus hidup perusahaan menjadi 4 tahapan yang berbeda. Pengelompokan observasi ke dalam 4 grup yang terpisah tersebut dilakukan berdasarkan 4 variabel, yaitu SGR, DIV, FIX, dan AGE. Hasil clustering yang dilakukan menggunakan fasilitas dalam program Stata disampaikan dalam tabel clustering. Bisa dilihat dalam hasil clustering untuk data yang digunakan dalam penelitian, kelompok dengan jumlah perusahaan observasi paling banyak adalah kelompok 2 yaitu 17 perusahaan, diikuti dengan kelompok 3 yang berisikan 7 perusahaan, kemudian kelompok 1 yang berisikan 5 perusahaan, dan terakhir yang anggotanya paling sedikit adalah kelompok 4, yaitu berisikan 4 perusahaan. Pada bagian selanjutnya dalam penelitian ini, kelompok 1 akan dinamakan kelompok perusahaan tahap pembentukan, kelompok 2 akan dinamakan kelompok perusahaan tahap pertumbuhan awal, kelompok 3 akan dinamakan kelompok perusahaan tahap pertumbuhan akhir, dan kelompok 4 akan dinamakan kelompok perusahaan tahap stabilitas. Hasil clustering ini nantinya akan digunakan sebagai dummy variabel dalam regresi yang akan dilaksanakan.

\section{Pemilihan Teknik Estimasi}

Untuk menentukan teknik estimasi yang akan digunakan dalam model penelitian, pertama-tama, Uji $\mathrm{F}$ test akan dilakukan. Pengujian $F$ Test yang dilakukan menghasilkan nilai statistik $F$ dan probabilitas yang nilainya signifikan, berarti hipotesis nol dari pengujian ini bisa ditolak dan diputuskan bahwa teknik estimasi yang akan digunakan dalam penelitian ini adalah metode fixed effect. Langkah berikutnya adalah melakukan Uji Hausman. Dari hasil regresi menggunakan metode random effect dan hasil Uji Hausman, probabilitas statistik chi2 yang dihasilkan memiliki nilai yang signifikan. Oleh karena itu, hipotesis nol 
bisa ditolak dan berarti penelitian ini akan menggunakan teknik estimasi fixed effect.

\section{Hasil Uji Asumsi Klasik}

Hasil uji normalitas serta pemeriksaan histogram untuk masing-masing variabel yang digunakan dalam penelitian ini menunjukkan bahwa data yang digunakan dalam penelitian ini tidak terdistribusi secara independen yang ada dalam masingmasing model. Melalui matriks korelasi, ditemukan bahwa variabel-variabel yang akan digunakan dalam model penelitian semuanya memiliki koefisien korelasi yang lebih kecil dari 0.8, menandakan tidak adanya masalah multikolinearitas.

Uji heteroskedastisitas dilakukan dengan menggunakan fasilitas pengujian Modified

Tabel 2 Hasil Clustering 33

\begin{tabular}{cccccc}
\hline Cluster & Jumlah & Mean DIV & Mean SGR & Mean FIX & Mean AGE \\
$\mathbf{1}$ & $\mathbf{5}$ & 0.300 & 0.169 & 0.397 & 21.400 \\
$\mathbf{2}$ & 17 & 0.329 & 0.100 & 0.367 & 35.765 \\
$\mathbf{3}$ & 7 & 0.466 & 0.107 & 0.294 & 49.857 \\
$\mathbf{4}$ & 4 & 0.793 & 0.099 & 0.374 & 79.750 \\
\hline
\end{tabular}

normal. Dari beberapa alternatif perlakuan yang dapat diberikan untuk distribusi yang tidak normal ini, diputuskan untuk tetap menggunakan metode estimasi fixed effect. Pelanggaran pada asumsi normalitas data ini secara umum dapat dipandang tidak terlalu parah apabila jumlah observasi yang digunakan cukup besar (Brooks, 2008). Gujarati (2004) berargumen bahwa asumsi normalitas ini khususnya dibutuhkan untuk penelitian yang menggunakan kurang dari 100 observasi. Penelitian dengan jumlah data kurang dari 100 observasi membutuhkan asumsi normalitas untuk dapat menghasilkan probabilitas estimator OLS yang tepat, sehingga analisis statistik $F$ dan statistik $t$ pun dapat digunakan dengan akurat. Namun, ketika jumlah observasi suatu penelitian relatif besar, asumsi normalitas tersebut dapat dikesampingkan. Jumlah observasi penelitian yang mencapai 231 observasi untuk set sampel yang digunakan dinilai telah cukup besar sehingga pelanggaran asumsi normalitas dianggap tidak akan berdampak parah pada estimasi yang dilakukan.

Uji multikolinearitas dilakukan dengan melihat matriks korelasi antar variabel
Wald Test for Groupwise Heteroskedasticity pada Stata. Hasil menunjukkan hasil probabilitas statistik chi2 yang signifikan. Artinya hipotesis nol dapat ditolak dan variasi error pada model yang digunakan dalam penelitian mengandung gejala heteroskedastisitas. Untuk bisa mengatasi adanya gejala heteroskedastisitas ini, maka dalam regresi akan digunakan opsi robust yang ada pada Stata. Opsi ini akan membuat standar error yang dihasilkan dari regresi menjadi bersifat robust sehingga dampak buruk dari adanya gejala heteroskedastisitas dapat dihindari dan tidak akan secara signifikan mempengaruhi hasil estimasi yang dilakukan.

Uji autokorelasi dilakukan dengan menggunakan fasilitas pengujian Woolridge Test yang ada dalam Stata. Hasil dari uji autokorelasi menunjukkan probabilitas statistik yang signifikan. Artinya hipotesis nol dapat ditolak dan dapat disimpulkan bahwa ditemukan adanya gejala autokorelasi dalam variabel-variabel yang digunakan dalam penelitian. Untuk mengatasi masalah tersebut, akan dilakukan penyesuaian teknik estimasi

regresi, yaitu dengan menggunakan re- 
gresi Driscoll-Kraay. Regresi fixed effect dengan menggunakan metode DriscollKraay tersebut akan menghasilkan standar error model yang sudah disesuaikan dengan adanya gejala heteroskedastisitas dan gejala autokorelasi dalam model, sehingga dampak buruk dari adanya dua gejala tersebut bisa diminimalisasi (Hoechle, 2007).

\section{Interpretasi Hasil Regresi}

Analisis statistik $\mathrm{F}$ dilakukan untuk memastikan kemampuan variabelvariabel independen yang digunakan dalam model penelitian untuk bersamasama mempengaruhi variasi pada variabel dependen. Karena model penelitian memasukkan variabel interaksi antara IVP dan OLC yang berbeda untuk setiap grup siklus hidup perusahaan, maka regresi akan dilakukan sebanyak 4 kali dengan masingmasing regresi tersebut memasukkan variabel dummy OLC yang berbeda. Variabel dummy OLC ini tidak bisa dimasukkan berbarengan dalam satu model karena akan menyebabkan masalah collinearity dan akan menyebabkan salah satu variabel dummy tersebut dihilangkan secara otomatis oleh program Stata. Semua model regresi menghasilkan probabilitas statistik $\mathrm{F}$ bernilai 0 , atau lebih kecil daripada a penelitian yang bernilai 0.05 . Hasil tersebut menunjukkan bahwa semua model penelitian bersifat signifikan secara statistik, atau dengan kata lain, semua variabel independen yang ada dalam model, bersama-sama dapat mempengaruhi variabel dependen ROA secara signifikan.

Analisis R2 dilakukan untuk melihat apakah model regresi yang digunakan dapat menjelaskan dengan baik variasi yang terjadi pada variabel dependen. Analisis ini juga akan dilakukan dengan jumlah dan iterasi yang sama dengan Hasilnya, nilai Within R2 untuk keempat model regresi penelitian menunjukkan angka yang cukup serupa, berkisar di angka $39-40 \%$. Nilai Within R2 yang cukup besar ini menunjukkan bahwa variabel-variabel independen yang digunakan dalam model berkinerja dengan cukup baik dan mampu menjelaskan sekitar $39-40 \%$ variasi yang terjadi pada variabel dependen. Analisis statistik $\mathrm{t}$ dilakukan untuk memeriksa signifikansi masingmasing variabel independen dalam setiap model terhadap

variabel dependen yang ada. Pada regresi dengan menggunakan metode fixed effect - Standard Error Driscoll-Kraay, ada dua variabel yang bernilai signifikan, yaitu IVP* ${ }^{*}$ 2 yang memiliki probabilitas 0.026 dan nilai koefisien sebesar 0.403278 , serta variabel IVP* $\mathrm{C} 3$ yang memiliki probabilitas statistik 0.042 dan nilai koefisien sebesar -0.43513 . Kedua variabel dalam regresi tersebut bernilai signifikan dengan menggunakan tingkat $\alpha=5 \%$.

Variabel IVP*C1 menghasilkan probabilitas statistik yang bernilai tidak signifikan, baik dengan menggunakan tingkat $\alpha=5 \%$ ataupun tingkat $\alpha=10 \%$.

Tabel 3 Hasil Regresi Penelitian

\begin{tabular}{lccc}
\hline & Hipotesis & Koefisien & Probabilitas \\
\hline IVP*C1 & $(-)$ & -0.42841 & 0.113 \\
IVP*C2 & $(+)$ & $\mathbf{0 . 4 0 3 2 7 8}$ & $\mathbf{0 . 0 2 6 ^ { * }}$ \\
IVP*C3 & $(-)$ & -0.43513 & $\mathbf{0 . 0 4 2 ^ { * }}$ \\
IVP*C4 & $(+)$ & 0.155499 & 0.782 \\
\hline
\end{tabular}

Ket.: * $=$ Signifikan pada tingkat $\alpha=5 \% ;{ }^{* *}=$ Signifikan pada tingkat $\alpha=10 \%$ 
Untuk memeriksa kesahihan hasil regresi ini, regresi dengan menggunakan metode clustered standar error juga dilakukan. Metode tersebut adalah alternatif lain untuk mengatasi masalah autokorelasi yang terdapat dalam data penelitian ini. Pada regresi dengan menggunakan metode clustered standard error, variabel $I V P^{*} \mathrm{C} 1$ ini bernilai signifikan dengan menggunakan tingkat $\alpha=10 \%$, dengan nilai koefisien variabel yang sama persis dengan koefisien variabel IVP ${ }^{*} \mathrm{C} 1$ pada regresi dengan menggunakan metode Driscoll-Kraay. Namun, karena dalam penelitian ini sudah ditetapkan bahwa metode regresi yang akan digunakan adalah metode Driscoll-Kraay, maka tetap saja hipotesis pertama tidak dapat dibuktikan, yaitu hipotesis yang menyatakan bahwa perusahaan-perusahaan yang berada dalam tahap pembentukan akan memiliki hubungan antara inventori dan kinerja finansial yang bersifat negatif. Variabel IVP*C1 bernilai tidak signifikan ini diduga disebabkan oleh beberapa hal. Pertama, diduga hal ini disebabkan oleh jumlah observasi yang sedikit, sehingga menyulitkan untuk membuat estimasi yang akurat. Dari total 33 perusahaan yang digunakan sebagai sampel dalam penelitian ini, hanya 5 perusahaan, atau sekitar $15 \%$, yang termasuk dalam kelompok pertama, yaitu kelompok tahapan siklus hidup pembentukan. Kedua, hal tidak signifikan ini diduga disebabkan oleh karakteristik perusahaan yang terdapat dalam kelompok tahapan siklus hidup pembentukan ini. Bila dilihat dari variabel usia perusahaan, kelima perusahaan yang terdapat dalam kelompok ini memiliki usia rata-rata sekitar 21 tahun, dengan usia minimal 15 tahun dan usia maksimal 28 tahun. Hal ini bisa dibilang berbeda dengan karakteristik perusahaanperusahaan yang secara umum berada dalam kelompok tahapan siklus hidup pembentukan.

Biasanya perusahaan- perusahaan yang berada dalam tahapan siklus hidup pembentukan ini adalah perusahaan yang baru dibentuk. Walaupun usia bukan faktor utama yang menentukan definisi tahapan siklus hidup perusahaan (Tam \& Gray, 2016), tetap saja secara umum perusahaan yang berada dalam tahapan siklus hidup pembentukan ini usianya biasanya masih muda dan tidak sampai lebih dari 10 tahun. Perbedaan karakteristik tersebut diduga dipengaruhi oleh peraturan-peraturan pasar modal yang ada di Indonesia. Penelitian ini mengambil sampel perusahaan-perusahaan yang terdaftar di bursa pasar saham Indonesia dan untuk sebuah perusahaan bisa mendaftarkan dirinya ke dalam bursa pasar saham itu, ada beberapa persyaratan yang harus dipenuhi, misalnya ada usia operasional minimal dan ada jumlah aset minimal yang harus dimiliki. Persyaratan tersebut diduga menghalangi perusahaanperusahaan startup yang cenderung masih muda dan belum memiliki nilai aset yang banyak untuk bisa masuk ke pasar modal.

Variabel IVP ${ }^{*} \mathrm{C} 2$ menghasilkan probabilitas statistik yang signifikan dan nilai koefisien sebesar 0.403278 pada regresi dengan menggunakan metode fixed effect (Driscoll- Kraay standard error). Nilai dan arah koefisien IVP ${ }^{*} \mathrm{C} 2$ ini juga sesuai dengan hipotesis awal yang menyatakan bahwa pada perusahaan- perusahaan yang berada dalam kelompok tahapan hidup pertumbuhan awal, hubungan antara inventori dan kinerja finansial perusahaan akan bersifat positif. Perusahaanperusahaan yang berada dalam kelompok tahapan hidup pertumbuhan awal ini biasanya sudah mengembangkan sistem operasi yang lebih stabil dibandingkan dengan perusahaan yang masih berada dalam kelompok tahapan hidup awal. Tingkat permintaan barang dari konsumen pun secara umum sudah lebih tinggi dan lebih stabil dibanding pada tahap awal.

Dengan mempertimbangkan konteks tersebut, apabila perusahaan mengambil keputusan untuk meningkatkan jumlah stok inventori, perusahaan akan dapat menikmati stok inventori tersebut terjual dan akan 
berubah menjadi keuntungan finansial bagi perusahaan. Stok inventori yang tinggi juga bisa menjamin risiko perusahaan kehabisan barang saat tingkat permintaan tinggi bisa dihindari. Semakin rendah jumlah stock-out yang terjadi, maka service-level perusahaan di mata konsumen akan semakin meningkat. Perusahaan yang memiliki service level semakin tinggi akan bisa mempertahankan konsumen yang sudah ada untuk melakukan pembelian ulang di masa mendatang dan malah berpotensi juga menarik konsumen baru untuk menjadi pelanggan dalam membeli produk perusahaan (Elsayed \& Wahba, 2016). Alasan itulah yang membuat hubungan antara inventori dan kinerja finansial perusahaan pada perusahaanperusahaan yang berada pada kelompok tahapan hidup pertumbuhan awal bersifat positif.

Variabel IVP*C3 menghasilkan probabilitas statistik yang signifikan pada tingkat $\alpha=5 \%$ dan nilai koefisien sebesar -0.43513 dengan menggunakan metode regresi fixed effect (Driscoll-Kraay standard error). Nilai dan arah

koefisien IVP* ${ }^{*} 3$ ini juga sesuai dengan hipotesis awal yang menyatakan bahwa pada perusahaan-perusahaan yang berada dalam kelompok tahapan hidup pertumbuhan akhir, hubungan antara inventori dan kinerja finansial perusahaan akan bersifat negatif. Perusahaanperusahaan yang berada dalam kelompok tahapan hidup pertumbuhan akhir ini masih mengalami tingkat pertumbuhan usaha yang positif, tapi laju pertumbuhannya akan mulai berkurang atau mengecil bila dibandingkan perusahaan yang berada pada tahapan hidup pertumbuhan awal (Elsayed \& Wahba, 2016). Perusahaan-perusahaan pada tahapan siklus hidup pertumbuhan akhir ini akan mulai memiliki kekuatan pasar dan akan mengakumulasi pangsa pasar yang semakin besar. Di sini, perusahaan akan mulai memprioritaskan untuk meningkatkan efisiensi dan mengurangi biaya-biaya yang terjadi, misalnya dengan menyeimbangkan antara service level dan biaya-biaya inventori yang mungkin timbul.

Perusahaan dengan pangsa pasar yang relatif besar dan tingkat permintaan yang stabil (dibandingkan saat perusahaan masih berada dalam tahapan siklus hidup pertumbuhan awal) akan menghadapi risiko stock-out yang lebih kecil dan biasanya perusahaan akan merespon hal tersebut dengan mengurangi tingkat stok inventori mereka. Bila pada laju pertumbuhan penjualan yang melambat ini perusahaan masih bersikeras untuk meningkatkan stok inventori, perusahaan malah akan menghadapi masalah baru terjadinya kelebihan inventori yang pada

ujungnya bisa menimbulkan biaya inventori rusak atau kadaluwarsa karena tidak kunjung terjual. Alasan itulah yang membuat hubungan antara inventori dan kinerja finansial perusahaan pada perusahaan-perusahaan yang berada pada kelompok tahapan hidup pertumbuhan akhir ini bersifat negatif.

Variabel IVP* ${ }^{*} 4$ menghasilkan nilai probabilitas statistik yang sama dengan variabel $I V P^{*} \mathrm{C} 1$, yaitu tidak signifikan, baik dengan menggunakan tingkat $\alpha=5 \%$ ataupun dengan menggunakan tingkat $\alpha=10 \%$. Dugaan penulis, variabel ini bisa bernilai tidak signifikan karena data observasi yang tersedia tidak memadai untuk membuat estimasi yang akurat. Dibandingkan kelompok siklus hidup lain, kelompok tahapan siklus hidup stabilitas ini adalah kelompok dengan jumlah anggota atau jumlah perusahaan paling sedikit. Dalam set sampel penelitian, perusahaan yang berada dalam kelompok tahapan siklus hidup stabilitas ini hanya berjumlah 4 dari total 33 perusahaan ( $12.1 \%$ dari total). Sedikitnya jumlah observasi ini diduga membuat estimasi menjadi sulit dilakukan sehingga menghasilkan probabilitas statistik yang akhirnya bersifat tidak signifikan.

Untuk memeriksa robustness hasil penelitian ini, penulis melakukan beberapa uji dengan metode lain. Pertama, penelitian 
ini mencoba untuk menggunakan set sampel yang berbeda dengan metode sampling unbalanced, yaitu sampling yang memperbolehkan data observasi tidak lengkap tetap dimasukkan sebagai observasi dalam penelitian. Hasilnya, didapat 177 perusahaan dengan periode observasi 17 tahun dari tahun 2000-2016. Namun regresi dengan menggunakan set sampel unbalanced ini menghasilkan nilai probabilitas statistik yang tidak signifikan untuk semua variabel utama penelitian. Metode stratified random sampling, yaitu metode sampling yang membagi populasi menjadi beberapa strata, dan kemudian secara acak memilih sampel dari masingmasing strata agar sampel yang dihasilkan pada akhirnya bersifat lebih representatif dan seimbang antar semua strata, juga sudah coba dilakukan. Metode stratified random sampling dilakukan dengan membagi populasi menjadi 4 strata berdasarkan variabel jumlah aset karena variabel aset ini salah satu penentu utama dalam menilai ukuran perusahaan terkait dengan siklus hidup organisasi. Kemudian dengan menggunakan Stata, penulis menentukan secara acak perusahaan dari masing-masing strata tersebut untuk dipilih sebagai sampel yang akan digunakan dalam penelitian.

Hasilnya didapat 62 perusahaan dengan periode observasi 7 tahun dari 2010- 2016 dan sifat observasi balanced atau semua data lengkap. Namun regresi dengan menggunakan set sampel yang didapat dengan menggunakan metode stratified sampling ini menghasilkan nilai probabilitas statistik yang tidak signifikan untuk semua variabel utama penelitian.

Kedua, selain menggunakan set sampel yang berbeda untuk diteliti, uji pemeriksaan robustness juga dilakukan dengan

menggunakan metode regresi yang berbeda. Selain metode Driscoll-Kraay, sebenarnya ada satu lagi alternatif solusi untuk masalah autokorelasi yang ditemukan dalam data penelitian, yaitu dengan menggunakan metode regresi clustered standard error. Clustering yang dilakukan terhadap standar error pada tingkatan unit observasi penelitian ini akan menghasilkan standard error yang bersifat robust dalam kondisi adanya gejala autokorelasi dalam model yang digunakan. Regresi yang dilakukan dengan menggunakan metode clustered standard error ini menghasilkan nilai probabilitas statistik yang signifikan pada tingkat $\alpha=10 \%$ untuk variabel IVP*C1 dan variabel IVP* $\mathrm{C} 2$, namun tidak signifikan untuk variabel IVP ${ }^{*} \mathrm{C} 3$ dan variabel IVP ${ }^{*} \mathrm{C} 4$. Hasil yang signifikan untuk variabel IVP* $\mathrm{C} 1$ juga disertai nilai koefisien variabel yang sesuai dengan hipotesis, yaitu sebesar -0.42841 .

Nilai dan arah koefisien ini sesuai dengan hipotesis awal yang sudah disampaikan sebelumnya bahwa perusahaanperusahaan yang berada dalam tahap pertumbuhan awal akan memiliki hubungan antara inventori dan kinerja finansial yang bersifat negatif. Perusahaan-perusahaan yang berada dalam kelompok tahapan siklus hidup awal secara umum belum memiliki tingkat permintaan yang besar dan volatilitas permintaan masih tinggi. Sistem operasi yang ada di dalam perusahaan-perusahaan dalam tahapan awal ini pun biasanya belum bersifat stabil. Apabila perusahaan mengambil keputusan untuk meningkatkan jumlah stok inventori yang dimiliki, maka kemungkinan besar stok inventori tersebut tidak akan mampu cepat diubah menjadi penjualan yang membawa keuntungan bagi perusahaan. Malah, stok inventori yang tinggi akan berisiko menambahkan biaya bagi perusahaan dalam bentuk biaya penyimpanan dan juga biaya apabila barang tersebut rusak atau kadaluwarsa. Oleh karena alasan itulah pada tahapan awal ini, hubungan antara inventori dan kinerja finansial perusahaan bersifat negatif. Untuk variabel IVP* $\mathrm{C} 2$ yang juga menghasilkan probabilitas statistik bernilai signifikan, nilai koefisien dengan menggunakan metode regresi clustered standard error ini 
menghasilkan arah dan nilai yang sama dibandingkan saat menggunakan metode regresi Driscoll-Kraay, yaitu 0.403278 .

Ketiga, pemeriksaan robustness juga dilakukan dengan menggunakan variabel yang berbeda saat proses clustering untuk membagi sampel ke dalam empat kelompok sesuai dengan tahapan siklus hidup organisasinya. Hasil penelitian yang telah disampaikan di atas menggunakan empat variabel sebagai kriteria siklus hidup organisasi, yaitu variabel DIV, SGR, FIX, dan AGE. Sebagai catatan, variabel DIV mengandung banyak observasi yang tidak lengkap sehingga untuk bisa menghasilkan data sampel yang bersifat balanced, banyak observasi tidak lengkap itu harus dikeluarkan dari sampel. Itulah salah satu penyebab sampel akhir yang digunakan dalam penelitian ini berjumlah relatif sedikit, yaitu hanya 33 perusahaan. Maka dari itu, untuk memeriksa robustness hasil penelitian, penulis juga mencoba menggunakan variabel kriteria siklus hidup organisasi yang berbeda, yaitu hanya menggunakan 3 variabel kriteria saja, SGR, FIX, dan AGE (Anthony \& Ramesh, 1992; Hasan \& Cheung, 2018). Namun, setelah proses clustering dilakukan dengan menggunakan tiga variabel tersebut dan kemudian dilanjutkan dengan regresi, ternyata hasil yang ada menunjukkan nilai probabilitas statistik yang tidak signifikan untuk semua variabel utama penelitian.

\section{SIMPULAN}

Tujuan utama penelitian ini adalah untuk melihat apakah siklus hidup organisasi perusahaan akan memiliki pengaruh dalam hubungan antara inventori dan kinerja finansial perusahaan. Penelitian ini menggunakan set sampel yang terdiri dari 33 perusahaan manufaktur yang terdaftar di BEI dalam rentang 7 tahun masa observasi dari tahun 2010-2016 dengan penyusunan data bersifat balanced. Regresi yang dilakukan untuk 4 variabel utama dalam penelitian, yaitu IVP* $\mathrm{C} 1, \mathrm{IVP}^{*} \mathrm{C} 2, \mathrm{IV} \mathrm{P}^{*} \mathrm{C} 3$,
IVP ${ }^{*} \mathrm{C} 4$, menunjukkan hasil probabilitas statistik yang signifikan untuk variabel IVP ${ }^{*} \mathrm{C} 2$ dan IVP ${ }^{*} \mathrm{C} 3$. Variabel IVP ${ }^{*} \mathrm{C} 2$ dan variabel IVP* $\mathrm{C} 3$ yang menghasilkan nilai probabilitas statistik yang signifikan, nilai koefisien variabel yang dihasilkan dari proses regresi sesuai dengan hipotesis awal, yaitu

\section{positif untuk variabel IVP ${ }^{*}$ C2 dan negatif untuk variabel IVP*C3.}

Koefisien variabel IVP*C2 yang signifikan dan bernilai positif menunjukkan bahwa pada perusahaan-perusahaan yang berada dalam kelompok tahapan hidup pertumbuhan awal, hubungan antara inventori dan kinerja finansial perusahaan akan bersifat positif. Dengan mempertimbangkan konteks tahapan hidup pertumbuhan awal, apabila perusahaan mengambil keputusan untuk meningkatkan jumlah stok inventori, perusahaan akan dapat menikmati stok inventori tersebut terjual dan akan berubah menjadi keuntungan finansial bagi perusahaan, serta akan meningkatkan service level perusahaan di mata konsumen (Elsayed \& Wahba, 2016). Alasan itulah yang membuat hubungan antara inventori dan kinerja finansial perusahaan pada perusahaan- perusahaan yang berada pada kelompok tahapan hidup pertumbuhan awal bersifat positif.

Koefisien variabel IVP* $\mathrm{C} 3$ yang signifikan dan bernilai negatif menunjukkan bahwa pada perusahaan-perusahaan yang berada dalam kelompok tahapan hidup pertumbuhan akhir, hubungan antara inventori dan kinerja finansial perusahaan akan bersifat negatif. Perusahaan- perusahaan yang berada pada tahapan hidup pertumbuhan akhir ini biasanya akan mengadopsi kebijakan yang bersifat risk- averse, memprioritaskan untuk meningkatkan efisiensi dalam perusahaan dan mengurangi biaya-biaya yang terjadi. Perusahaan pada tahapan ini biasanya mengurangi tingkat stok inventori mereka. Bila pada laju pertumbuhan penjualan yang melambat ini perusahaan masih bersikeras 
untuk meningkatkan stok inventori, perusahaan malah akan menghadapi masalah baru terjadinya kelebihan inventori yang pada ujungnya bisa menimbulkan biaya inventori rusak atau kadaluwarsa karena tidak kunjung terjual. Alasan itulah yang membuat hubungan antara inventori dan kinerja finansial perusahaan pada perusahaan-perusahaan yang berada pada kelompok tahapan hidup pertumbuhan akhir ini bersifat negatif.

Variabel IVP ${ }^{*} \mathrm{C} 1$ dan variabel IVP $^{*} \mathrm{C} 4$ bernilai tidak signifikan, paling utama diduga disebabkan karena sedikitnya jumlah perusahaan yang termasuk dalam kelompok tahapan siklus hidup pembentukan $\left(\mathrm{IVP}^{*} \mathrm{C} 1\right)$ dan kelompok tahapan siklus hidup stabilitas (IVP*C4). Penyebab lain yang kedua terkait dengan karakteristik perusahaan dalam kelompok tahapan siklus hidup pembentukan yang memiliki rata-rata usia lebih tinggi dibanding rata-rata usia perusahaan dalam tahap pembentukan pada umumnya. Perbedaan ini diduga karena adanya persyaratan yang menghalangi perusahaan- perusahaan startup untuk bisa memasuki bursa pasar saham di Indonesia, tempat yang menjadi sumber sampel penelitian ini.

Hasil penelitian ini menunjukkan hasil yang berbeda dengan penelitian yang dijadikan acuan. Penelitian Elsayed \& Wahba (2016) menunjukkan hasil yang signifikan untuk semua variabel utama penelitian sehingga bisa secara meyakinkan menunjukkan bahwa faktor siklus hidup organisasi mempengaruhi hubungan antara inventori dan kinerja finansial di 4 kelompok tahapan siklus hidup yang berbeda. Perbedaan hasil penelitian ini pertamatama diduga karena perbedaan jumlah perusahaan yang digunakan dalam sampel. Walaupun sama-sama menggunakan perusahaan dalam industri manufaktur, jumlah perusahaan yang menjadi sampel penelitian berbeda. Penelitian Elsayed \& Wahba (2016) menggunakan 84 perusahaan dengan total 504 observasi dalam sampel penelitiannya, sedangkan penelitian ini hanya menggunakan 33 perusahaan dengan total 231 observasi dalam sampel penelitian. Kemudian karakteristik perusahaan yang digunakan dalam sampel pun bisa dilihat berbeda. Dalam penelitian Elsayed \& Wahba (2016), kelompok tahapan siklus hidup pembentukan berisikan 40 observasi dengan rata-rata usia sekitar 6 tahun. Sedangkan dalam penelitian ini, kelompok tahapan siklus hidup pembentukan berisikan 35 observasi (5 perusahaan dikali 7 tahun observasi) dengan rata-rata usia sekitar 21 tahun. Perbedaan rata-rata usia yang cukup signifikan tersebut diduga disebabkan oleh perbedaan peraturan bursa pasar saham masing-masing negara dalam mensyaratkan perusahaan untuk bisa mendaftarkan dirinya. Kemungkinan untuk saat ini peraturan di bursa pasar saham negara Mesir lebih memudahkan sehingga banyak perusahaan yang berusia muda tetap bisa mendaftarkan dirinya di sana

dan pada akhirnya bisa masuk ke dalam sampel penelitian. Dengan informasi yang didapat dari penelitian ini, pihak manajemen perusahaan dapat membuat keputusan yang lebih akurat terkait manajemen inventori di dalam perusahaannya. Selama ini, pandangan umum yang berlaku menganggap bahwa tingkat inventori yang paling baik adalah bila dijaga pada tingkat minimal. Semakin kecil tingkat inventori, maka manajemen inventori dinilai efisien dan tidak akan menimbulkan biaya seperti biaya penyimpanan ataupun biaya inventori yang kedaluwarsa (Silver, 1981). Namun, ternyata hal tersebut tidak selamanya benar dan tepat. Dari sekian banyaknya faktor yang harus dipertimbangkan oleh seorang manajer dalam mengelola inventori, penelitian ini memberipenekanan pentingnya seorang manajer mempertimbangkan siklus hidup organisasi saat membuat keputusan terkait dengan manajemen inventori. Ketika akan membuat keputusan, seorang manajer yang bertugas untuk mengelola inventori perusahaan sebaiknya terlebih dahulu 
melakukan analisis dan penilaian, apakah saat itu perusahaan berada dalam tahapan siklus hidup pembentukan, tahapan siklus hidup pertumbuhan awal, tahapan siklus hidup pertumbuhan akhir, atau tahapan siklus hidup stabilitas. Seperti yang sudah dijelaskan di bagian sebelumnya, keempat tahapan siklus hidup tersebut memiliki karakteristik masing- masing yang seharusnya memudahkan manajer untuk melihat dan menentukan, misalnya dilihat dari usia perusahaan, tingkat pertumbuhan penjualan perusahaan, nilai aset perusahaan, pangsa pasar yang dimiliki perusahaan, kekuatan perusahaan bersaing dengan kompetitornya, dan beberapa faktor lainnya (Anthony \& Ramesh, 1992). Setelah penilaian dan analisis terkait siklus hidup organisasi sudah dibuat, barulah sebaiknya manajer membuat keputusan terkait dengan inventori, apakah sebaiknya menjaga inventori pada tingkat yang rendah untuk mendapat efisiensi biaya dan menghindari biaya yang tidak perlu, atau meningkatkan inventori untuk antisipasi permintaan dari pembeli dan menghindari biaya dari adanya stockout atau biaya saat perusahaan tidak dapat memenuhi permintaan pembeli.

Ada beberapa kekurangan yang menyebabkan kesimpulan yang ada kurang akurat. Pertama-tama, penelitian ini terbatas dalam hal akurasi data yang digunakan. Semua data yang digunakan dalam penelitian ini pertama-tama dikumpulkan dengan menggunakan Wharton Research Data Centre (WRDC). Karena ada beberapa observasi yang tidak lengkap, penulis mencoba untuk melengkapinya dengan menggunakan referensi softcopy laporan keuangan perusahaan dari website BEI, ataupun dari website resmi perusahaan terkait. Ternyata, setelah data dari laporan keuangan tersebut dibandingkan dengan data yang tersedia pada database WRDS, ada beberapa perbedaan nilai, yang beberapa di antaranya cukup signifikan. Ketidakakuratan database WRDS ini mungkin disebabkan oleh perbedaan metode penghitungan masing-masing variabel yang dibutuhkan. Ke depannya, mungkin penggunaan database seperti ini perlu disertai dengan pengujian akurasi data yang lebih ekstensif. Apabila memungkinkan, pengumpulan data manual dari laporan keuangan satu per satu juga diyakini akan menghasilkan data yang lebih akurat, walaupun tentu saja membutuhkan waktu yang lebih panjang.

Keterbatasan dan saran yang kedua masih terkait dengan masalah sampling. Seperti yang sudah dijelaskan di bagian sebelumnya, salah satu dugaan penyebab beberapa variabel utama penelitian bernilai tidak signifikan terkait dengan karakteristik perusahaan dalam sampel yang memiliki rata-rata usia tidak sesuai dengan karakteristik usia perusahaan pada tahapan siklus hidup pembentukan pada umumnya. Karena masalah ini salah satunya disebabkan oleh pengambilan sampel penelitian yang berasal dari perusahaanperusahaan yang terdaftar dalam bursa pasar saham, maka ada dua saran untuk penelitian ke depannya dan juga saran untuk pihak Bursa Efek Indonesia (BEI). Saran pertama, bila memungkinkan penelitian bisa juga menggunakan sampel dari perusahaanperusahaan startup yang belum terdaftar di BEl. Dengan memastikan perusahaanperusahaan di luar BEI tersebut juga sudah melaksanakan proses pelaporan keuangan yang sesuai standar dan sudah diaudit, maka data-data yang diperoleh menjadi bisa dibandingkan dengan data-data perusahaan yang sudah terdaftar di BEl. Dengan begitu, perusahaan-perusahaan startup yang berusia muda dan memiliki nilai aset masih kecil juga akhirnya bisa terwakili dan masuk ke dalam set sampel penelitian. Saran kedua untuk pihak BEl, bila memungkinkan, syarat, peraturan, dan regulasi terkait perusahaan mana yang boleh mendaftar masuk ke bursa saham sebaiknya dibuat menjadi lebih memudahkan bagi perusahaanperusahaan yang relatif masih kecil dan muda. Apabila peraturan dan regulasi 
tersebut dipermudah dan disederhanakan, maka jumlah perusahaan yang listing akan meningkat, perusahaan tersebut akan mendapat dana yang lebih banyak melalui pasar saham, dan pada akhirnya berpotensi akan berdampak positif pada perputaran roda ekonomi nasional.

Keterbatasan yang ketiga adalah terkait dengan metode clustering yang digunakan dalam penelitian ini, yaitu metode K-mean. Walaupun metode ini memiliki kelebihan dalam hal kesederhanaan penghitungan, metode $\mathrm{K}$ - mean ini juga memiliki kekurangan tentang pemilihan jumlah kelompok cluster yang dilakukan secara manual oleh peneliti. Sebelum melakukan proses analisis clustering, peneliti harus terlebih dahulu menentukan mau membagi sampel yang ada menjadi berapa kelompok. Kadang, jumlah kelompok yang ditentukan oleh peneliti tersebut bisa jadi tidak akurat karena tidak sesuai dengan data yang ada. Metode yang lebih baik terkait keterbatasan tersebut adalah metode clustering Ward's
Algorithm, sebuah metode clustering yang dapat menentukan sendiri jumlah kelompok yang paling optimal dari set sampel data yang tersedia. Dengan penentuan jumlah kelompok dihasilkan dari algoritma perhitungan, masalah subjektivitas peneliti dapat dihindari dan jumlah kelompok yang dihasilkan pun akan bisa lebih disesuaikan dengan karakteristik data yang digunakan dalam penelitian. Penelitian kali ini menggunakan metode K-mean karena sejak awal sudah mengetahui akan membagi sampel ke dalam 4 kelompok yang berbeda sesuai dengan literatur siklus hidup organisasi (Lyden, 1975; Kazanjian \& Drazin, 1990). Namun apabila dengan menggunakan Ward's Algorithm ditemukan bahwa jumlah kelompok

yang optimal bukanlah 4, melainkan 3 atau 5 misalnya, maka peneliti juga bisa mencari landasan teori siklus hidup organisasi yang sesuai dengan jumlah kelompok tersebut.

\section{DAFTAR PUSTAKA}

Andari, B. (2016). The Importance Of The Raw Materials Inventory Supervision For Production Process. Journal of Academic Research and Sciences, 1(1), 53-60.

Ardianti, R. (2013). Firm's Obstacles and Survival: The Study of Firm's Life Cycle and Obstacles in Indonesia. Jurnal Manajemen Teknologi, 12(2), 184-194.

Bendig, D., Brettel, M., \& Downar, B. (2018). Inventory Component Volatility and Its Relation to Stock Returns. International Journal of Production Economics. https://doi.org/10.1016/j. ijpe.2018.03.012

Blazenko, G. W., \& Vandezande, K. (2003). Corporate holding of finished goods inventories. Journal of Economics and Business, 55(3), 255-266. https://doi.org/10.1016/S01486195(03)00023-7

Brooks, Chris. (2008). Introductory econometrics for finance (2nd ed.). Cambridge University Press. Cannon, A. R. (2008). Inventory improvement and financial performance. International Journal of

Production Economics, 115(2), 581-593. https://doi.org/10.1016/j.jpe.2008.07.006

Capkun, V., Hameri, A., \& Weiss, L. A. (2009). On the relationship between inventory and financial performance in manufacturing companies. International Journal of Operations \& Production Management, 29(8), 789-806. https://doi.org/10.1108/01443570910977698

Cooper, R., \& Maskell, B. (2008). How to Manage Through Worse-Before-Better. MIT Sloan Management Review, 49(4), 57-66. 
Dai, J., Peng, S., \& Li, S. (2017). Mitigation of Bullwhip Effect in Supply Chain Inventory Management Model. Procedia Engineering, 174, 1229-1234. https://doi.org/10.1016/j. proeng.2017.01.291

De Vries, J. (2011). The shaping of inventory systems in health services: A stakeholder analysis. International Journal of Production Economics, 133(1), 60-69. https://doi.org/10.1016/j. ijpe.2009.10.029

Demeter, K. (2003). Manufacturing strategy and competitiveness. International Journal of Production Economics, 81-82, 205-213. https://doi.org/10.1016/S0925-5273(02)003535

Dodge, H. R., Fullerton, S., \& Robbins, J. E. (1994). Stage of the Organizational Life Cycle and Competition as Mediators of Problem Perception for Small Businesses Author ( $\mathrm{s}$ ): $\mathrm{H}$. Robert Dodge, Sam Fullerton and John E . Robbins Published by : Wiley Stable URL : http://www.jstor.org/stable/2486867 REFERE. Strategic Management Journal, 15(2), 121-134.

Elsayed, K., \& Wahba, H. (2016). Reexamining the relationship between inventory management and firm performance: An organizational life cycle perspective. Future Business Journal, 2(1), 65- 80. https://doi.org/10.1016/j.fbj.2016.05.001

Eroglu, C., \& Hofer, C. (2011). Lean, leaner, too lean? the inventory-performance link revisited. Journal of Operations Management, 29(4), 356-369. https://doi.org/10.1016/j. jom.2010.05.002

Gaur, V., \& Kesavan, S. (2007). The effects of firm size and sales growth rate on inventory turnover performance in the U.S. retail sector. International Series in Operations Research and Management Science, 223, 25-52. https://doi.org/10.1007/978-1-4899-7562-1_3

Gujarati, Damodar N. (2004). Basic Econometrics (4th ed.). McGraw-Hill Companies.

Hasan, M. M., \& Cheung, A. (Wai K. (2018). Organization capital and firm life cycle. Journal of 17

Corporate Finance, 48, 556-578. https://doi.org/10.1016/j.jcorpfin.2017.12.003

Heil, M. W. (2014). An Integrated, Holistic Approach to Organization Development: A Case Study of Increasing Enduring Organization Efficiency through Life Cycle Transformation Assessment. Proquest Dissertations Publishing.

Hendricks, K. B., \& Singhal, V. R. (2005). An Empirical Analysis of the Effect of Supply Chain Disruptions on Stock Price Performance and Equity Risk of the Firm. Production and Operation Management, 14(Spring), 35-52.

Hendricks, K. B., \& Singhal, V. R. (2009). Demand-Supply Mismatches and Stock Market Reaction: Evidence from Excess Inventory Announcements. Manufacturing \& Service Operations Management, 11(3), 509-524. https://doi.org/10.1287/msom.1080.0237

Hendricks, K. B., Singhal, V. R., \& Stratman, J. K. (2007). The impact of enterprise systems on corporate performance: A study of ERP, SCM, and CRM system implementations. Journal of Operations Management, 25(1), 65-82. https://doi.org/10.1016/j.jom.2006.02.002

Hoechle, D. (2007). Robust Standard Errors for Panel Regressions with Cross-Sectional Dependence. Stata Journal, (ii), 1-31.

Hofer, C., Eroglu, C., \& Rossiter Hofer, A. (2012). The effect of lean production on financial performance: The mediating role of inventory leanness. International Journal of Production Economics, 138(2), 242-253. https://doi.org/10.1016/j.jpe.2012.03.025

Kazanjian, R. K., \& Drazin, R. (1990). A Stage-Contingent Model of Design and Growth for Techonology Based New Ventures. Journal of Business Venturing, 5, 137-150.

Klingenberg, B., Timberlake, R., Geurts, T. G., \& Brown, R. J. (2013). The relationship of operational innovation and financial performance - A critical perspective. International Journal of 
Production Economics, 142(2), 317-323. https://doi.org/10.1016/j.ijpe.2012.12.001

Kolias, G. D., Dimelis, S. P., \& Filios, V. P. (2011). An empirical analysis of inventory turnover behaviour in Greek retail sector. International Journal of Production Economics, 133(1), 143- 153. https://doi.org/10.1016/j.ijpe.2010.04.026

Koumanakos, D. P. (2008). The effect of inventory management on firm performance. International Journal of Productivity and Performance Management, 57(5), 355-369. https://doi.org/10.1108/17410400810881827

Liao, H., \& Brooks, G. (2016). Outlier Impact and Accommodation Methods : Multiple Comparisons of Type I Error Rates. Journal of Modern Applied Statistical Methods, 15(1). https://doi.org/10.22237/jmasm/1462076520

Lyden, F. J. (1975). Using Parsons â€TM Functional Analysis in the Study of Public Organizations. Administrative Science Quarterly, 20(1), 59-70.

Mishra, S., Modi, S. B., \& Animesh, A. (2013). The relationship between information technology capability, inventory efficiency, and shareholder wealth: A firm-level empirical analysis. Journal of Operations Management, 31(6), 298-312. https://doi.org/10.1016/j. jom.2013.07.006

Moser, P., Isaksson, O. H. D., \& Seifert, R. W. (2017). Inventory dynamics in process industries: An empirical investigation. International Journal of Production Economics, 191(June), 253-266. https://doi.org/10.1016/j.ijpe.2017.06.019

Nemtajela, N., \& Mbohwa, C. (2017). Relationship between Inventory Management and Uncertain Demand for Fast Moving Consumer Goods Organisations. Procedia Manufacturing, 8(October 2016), 699-706. https://doi.org/10.1016/j.promfg.2017.02.090

Obermaier, R., \& Donhauser, A. (2012). Zero inventory and firm performance: A management paradigm revisited. International Journal of Production Research, 50(16), 4543-4555.

18

https://doi.org/10.1080/00207543.2011.613869

Rabinovich, E., Dresner, M. E., \& Evers, P. T. (2003). Assessing the effects of operational processes and information systems on inventory performance. Journal of Operations Management, 21(1), 63-80. https://doi.org/10.1016/S0272-6963(02)00041-4

Rahimi, F., \& Fallah, S. (2015). Study of Organizational Life Cycle and its Impact on Strategy Formulation. Procedia - Social and Behavioral Sciences, 207, 50-58. https://doi. org/10.1016/j.sbspro.2015.10.152

Shah, R., \& Shin, H. (2007). Relationships among information technology, inventory, and profitability: An investigation of level invariance using sector level data. Journal of Operations Management, 25(4), 768-784. https://doi.org/10.1016/j.jom.2007.01.011

Silver, E. A. (1981). Operations Research in Inventory Management : A Review and Critique Author ( $s$ ): Edward A. Silver Published by : INFORMS Stable URL : http://www.jstor.org/ stable/170382 REFERENCES Linked references are available on JSTOR for this article : You may need. INFORMS - Operation Research, 29(4), 628-645.

Srivathsan, S., \& Kamath, M. (2018). Understanding the value of upstream inventory information sharing in supply chain networks. Applied Mathematical Modelling, 54, 393-412. https:// doi.org/10.1016/j.apm.2017.09.004

Steinker, S., \& Hoberg, K. (2013). The impact of inventory dynamics on long-term stock returns - An empirical investigation of U.S. manufacturing companies. Journal of Operations Management, 31(5), 250-261. https://doi.org/10.1016/j.jom.2013.05.002

Tam, S., \& Gray, D. E. (2016). What Can We Learn from the Organizational Life Cycle Theory ? A Conceptualization for the Practice of Workplace Learning. Journal of Management Research, 8(2), 18-30. https://doi.org/10.5296/jmr.v8i2.9093 
Vastag, G., \& Whybark, D. C. (2005). Inventory management: Is there a knock-on effect? International Journal of Production Economics, 93-94(SPEC.ISS.), 129-138. https://doi. org/10.1016/j.ijpe.2004.06.011

Waller, M. A., \& Esper, T. L. (2014). The Definitive Guide To Inventory Management. Council of Supply Chain Management Professionals. 